Bull. Chem. Soc. Ethiop. 2020, 34(2), 335-351.

ISSN 1011-3924

(c) 2020 Chemical Society of Ethiopia and The Authors

Printed in Ethiopia

DOI: https://dx.doi.org/10.4314/bcse.v34i2.11

\title{
SYNTHESIS, STRUCTURAL, SPECTRAL AND BIOLOGICAL EVALUATION OF METALS ENDOWED 1,2,4-TRIAZOLE
}

\author{
Sajjad Hussain Sumrra ${ }^{1 *}$, Muhammad Anees ${ }^{1}$, Awais Asif ${ }^{2}$, Muhammad Nadeem Zafar ${ }^{1}$, Khalid \\ Mahmood $^{3}$, Muhammad Faizan Nazar ${ }^{1}$, Muhammad Khalid ${ }^{4}$, Muhammad Arif Nadeem ${ }^{5}$ and \\ Muhammad Usman Khan ${ }^{6}$ \\ ${ }^{1}$ Department of Chemistry, University of Gujrat, Gujrat-50700, Pakistan \\ ${ }^{2}$ Department of Biochemistry, Nawaz Sharif Medical College, University of Gujrat, \\ Gujrat-50700, Pakistan \\ ${ }^{3}$ Institute of Chemical Sciences, Bahauddin Zakariya University, Multan-60800, Pakistan \\ ${ }^{4}$ Department of Chemistry, Khwaja Fareed University of Engineering and Information \\ Technology, Rahim Yar Khan-64200, Pakistan \\ ${ }^{5}$ Department of Chemistry, Quaid-i-Azam University, Islamabad-45320, Pakistan \\ ${ }^{6}$ Department of Applied Chemistry, Government College University, Faisalabad-38000, \\ Pakistan
}

(Received November 29, 2019; Revised July 28, 2020; Accepted July 29, 2020)

\begin{abstract}
Biologically active triazole Schiff base ligand 2,4-dichloro-6-[(1H-1,2,4-triazol-3ylimino)methyl]phenol (A) has been synthesized by the condensation reaction of an equimolar amount of $1 \mathrm{H}$ 1,2,4-triazole-3-amine and 3,5-dichlorosalicylaldehyde and then it coordinated with salts of metals [VO(IV), $\mathrm{Fe}(\mathrm{II}), \mathrm{Co}(\mathrm{II}), \mathrm{Ni}(\mathrm{II}), \mathrm{Cu}(\mathrm{II})$ and $\mathrm{Zn}$ (II)] in 2:1 molar ratio to derive a series of transition metal chelates (1)-(6). All the compounds were characterized by various physical, spectral, analytical techniques and elemental analysis. Spectral characterization and magnetic moment data of complexes revealed square pyramidal geometry for vanadium complex and octahedral for remaining (2)-(6) complexes. Quantum chemical calculation has been carried out to explore optimized geometry and electronic structure of the ligand. Density functional theory (DFT) with B3LYP/6-311 $+\mathrm{g}(\mathrm{d}, \mathrm{p})$ method was performed to determine vibrational bands, frontier molecular orbitals (FMOs) and natural bond analysis (NBO) of the ligand. NBO analysis showed that the ligand bears higher molecular stability because of hyper conjugate interactions. Computational study results revealed that there was a close interaction of theoretical and experimental spectroscopic data. Global reactivity descriptors calculated by the energies of FMOs, indicated ligand to be bioactive. The synthesized compounds were studied for antibacterial, antifungal, antioxidant and antiglycation activity and the results revealed that ligand has remarkable activity which considerably increased upon chelation.
\end{abstract}

KEY WORDS: Triazole ligand, Transition metal chelates, Antibacterial, Antifungal, Antioxidant, Computational study

\section{INTRODUCTION}

For the last two decades, Schiff bases were in continuous surfacing due to their ease in preparation and variety of chemical reactions [1]. Schiff bases form an important class of extensively used organic compounds and have various applications in different fields including biological, analytical and inorganic chemistry [2]. Literature revealed that the reactivity of Schiff bases enhanced significantly in the presence of $\mathrm{OH}$ group, primarily when the $\mathrm{OH}$ group is attached at ortho position [3]. Schiff bases exhibit various biological activities and these activities were increased by coordination with metal ions [4]. Various transition metals coordinated with bi, tri and tetradentate Schiff base ligands having sulphur, nitrogen and oxygen donor atoms which have played significant role in biological systems [5]. In contrast to $4 d$ and $5 d$ transition metal complexes, $3 d$ metal complexes have revealed valuable imperative properties as they can easily enter to the microbial cell membrane and have low toxicity [6].

*Corresponding author. E-mail: sajjadchemist@uog.edu.pk

This work is licensed under the Creative Commons Attribution 4.0 International License 
Microbial infection is the common growing health problem in contemporary medicinal field and the use of antibiotic drugs is inevitable. Regardless of the availability of several antibiotic and chemotherapeutic drugs, the emergence of various old and new antibiotic resistant bacterial species created a substantial need for the innovative classes of antibacterial agents [7]. Design and development of new metal-based drugs is an effective approach to fight against the current threat of anticancer, antimicrobial and antioxidant resistance [8]. Therefore, compounds which show activity against resistant strains, with enhanced safety and pharmacokinetic profiles are the main goals for the current and future researchers in this area [9].

Triazole is a heterocyclic ring that is considered as pharmacologically imperative scaffold and certainly used in many drugs associated with various biological activities [10]. Triazole based transition metal complexes have shown substantial pharmaceutical and biological activities such as antibacterial [11], antifungal [12], anticancer [13], herbicidal [14], cytotoxic [15], antidiabetic [16], DNA binding and cleavage [17], anti-inflammatory and have abilities to reduce the radical scavenging as well as oxidative properties [18]. Motivated by the above mentioned facts and in the continuation of our research work [19] for biologically potent nitrogen and oxygen endowed transition metal complexes; in the present paper we wish to report the facile synthesis of another novel nitrogen based triazole Schiff base, 2,4-dichloro-6-[(1H1,2,4-triazol-3-ylimino)methyl]phenol by the condensation reaction of $1 H$-1,2,4-triazol-3-amine and 3,5-dichlorosalicylaldehyde and its transition metal complexes [VO(IV), Fe(II), Co(II), $\mathrm{Ni}(\mathrm{II}), \mathrm{Cu}(\mathrm{II})$ and $\mathrm{Zn}(\mathrm{II})$ ] (Scheme 1). In addition to the synthesis of these compounds, elucidation of their chemical structures was done by different spectroscopic techniques and DFT based calculations. Furthermore, the investigated compounds were screened for antibacterial, antiglycation, antifungal and antioxidant activities.

\section{EXPERIMENTAL}

Analytical grade chemicals purchased from authentic sources were used in this research; Sigma Aldrich and Merck. Distilled ethanol and methanol were used in synthetic reaction of ligand and its transition metal complexes, respectively. Stuart instrument was used for the determination of melting point of synthesized ligand and its metal complexes. A high tech Shimadzu UV-4000 Spectrophotometer was used for UV-Vis analysis. Infrared spectroscopic technique was used for the purpose of recording the wavelength of solid sample at $600-4000 \mathrm{~cm}^{-1}$ with the help of Nicolet FT-IR Impact 400D infra-red spectrometer. ${ }^{1} \mathrm{H}$ and ${ }^{13} \mathrm{CNMR}$ of synthesized ligand was performed by using Bruker Advance $300 \mathrm{MHz}$ (Bruker Biospin GMBH Rheinstetten, Germany). For the mass spectrometric analysis, ligand was dissolved in $\mathrm{MeOH}$ and injected directly through direct insertion pump into the LTQ XL Linear Ion Trap Mass Spectrometer (Thermo Scientific, USA) equipped with an Electro Spray Ionization (ESI) probe. Ligand was analyzed in both positive as well as negative ion modes with a $10 \mu \mathrm{L} \mathrm{min}{ }^{-1}$ flow rate. Capillary temperature and sheath gas flow $\left(\mathrm{N}_{2}\right)$ were set at $350{ }^{\circ} \mathrm{C}$ and 30 arbitrary units, respectively. Then, data was attained at both negative and positive total ion full scan mode with a range of mass scan of $m / z$ 50-700 using Xcalibur software. The full scan ESI-mass spectrum was used to characterize the ligand, which gave specific $\mathrm{m} / \mathrm{z}$ peaks by producing $[\mathrm{M}+\mathrm{Na}]^{+},[\mathrm{M}-\mathrm{H}]^{-}$and $[\mathrm{M}+\mathrm{H}]^{+}$ions. Moreover, the ESI-MS/MS fragmentation pattern of recognized peaks was used to produce the daughter ions to confirm the molecular identity of ligand. All the antibacterial and antifungal activities were performed at Department of Biochemistry, Nawaz Sharif Medical College, University of Gujrat, Gujrat, Pakistan and antioxidant activity was carried out at Department of Chemistry, University of Gujrat, Gujrat, Pakistan.

\section{Synthesis of ligand}

To synthesize ligand (A), magnetically refluxed $10 \mathrm{~mL}$ ethanolic solution of 3,5dichlorosalicylaldehyde $(0.191 \mathrm{~g}, 1 \mathrm{mmol})$ was added in double neck flask with continuous 
stirring. After half an hour of refluxing, $1 H$-1,2,4-triazol-3-amine $(0.084 \mathrm{~g}, 1 \mathrm{mmol})$ was added. The reaction was continuously monitored by performing thin layer chromatography (TLC). The pale-yellow precipitates of the product were obtained after refluxing of 6 hours (Scheme 1). The precipitated product was cooled at room temperature overnight followed by filtration, washing and drying. The obtained product was recrystallized in a mixture of ethanol and dioxane at room temperature to get pure compound.

\section{2,4-Dichloro-6-[(1H-1,2,4-triazol-3-ylimino)methyl]phenol (A)}

Yield (94\%); melting point $231{ }^{\circ} \mathrm{C}$; color pale yellow; IR $\left(\mathrm{KBr}, \mathrm{cm}^{-1}\right): 3180(\mathrm{OH}), 3070(\mathrm{NH})$, $1640\left(\mathrm{HC}=\mathrm{N}\right.$, azomethine), $1585\left(\mathrm{C}=\mathrm{N}\right.$, triazole), $1380(\mathrm{C}-\mathrm{O}), 1020(\mathrm{~N}-\mathrm{N}) ;{ }^{1} \mathrm{H}$ NMR (DMSO$\left.\mathrm{d}_{6}\right): \delta 7.76\left(\mathrm{~d}, \mathrm{C}_{9}-\mathrm{H}\right), 7.92\left(\mathrm{~d}, \mathrm{C}_{12}-\mathrm{H}\right), 8.64\left(\mathrm{~s}, \mathrm{C}_{1}-\mathrm{H}\right), 9.41\left(\mathrm{~s}, \mathrm{C}_{13}-\mathrm{H}\right), 13.85\left(\mathrm{~s}, \mathrm{C}_{8}-\mathrm{OH}\right), 14.29(\mathrm{~s}$, $\left.\mathrm{C}_{1}-\mathrm{NH}\right) ;{ }^{13} \mathrm{C}$ NMR (DMSO-d $\left.6, \delta, \mathrm{ppm}\right): 121.10\left(\mathrm{C}_{7}\right), 122.05\left(\mathrm{C}_{10}\right), 123.29\left(\mathrm{C}_{11}\right), 131.56\left(\mathrm{C}_{9}\right)$, $133.30\left(\mathrm{C}_{8}\right), 135.50\left(\mathrm{C}_{12}\right), 145.18\left(\mathrm{C}_{1}\right), 155.66\left(\mathrm{C}_{5}\right), 164.73\left(\mathrm{C}_{13}\right)$; EIMS $m / z(\%): 257.08\left[\mathrm{M}^{+}\right]$, 256.83 (19), 238.67 (75), 208.75 (6), 194.83 (78), 180.17 (100), 166.25 (46), 157.25 (12), 122.33 (9); anal. calcd. for $\mathrm{C}_{9} \mathrm{H}_{6} \mathrm{Cl}_{2} \mathrm{~N}_{4} \mathrm{O}(257.08) \%$ : C, 42.05; $\mathrm{H}, 2.35 ; \mathrm{N}, 21.79$; found: $\mathrm{C}, 41.80$; H, 2.26; N, 21.60.

\section{Synthesis of transition metal complexes}

All the transition metal chelates were synthesized by using standard procedure with molar ratio of ligand and metal salts $2: 1$. In this method, $(2.57 \mathrm{~g}, 10 \mathrm{mmol})$ of ligand was mixed with methanol in double neck flask and refluxed for half an hour. After that, respective metallic salt $(5 \mathrm{mmol})$ was added and reaction was monitored by using TLC. Different metallic salts were used at different time for complex formation. After 5-7 hours of refluxing, precipitates of metal complexes were formed; precipitates were separated by filtration and were cooled at room temperature over night. The produced metal complexes were recrystallized in a mixture of methanol and dioxane at room temperature to get pure compound.

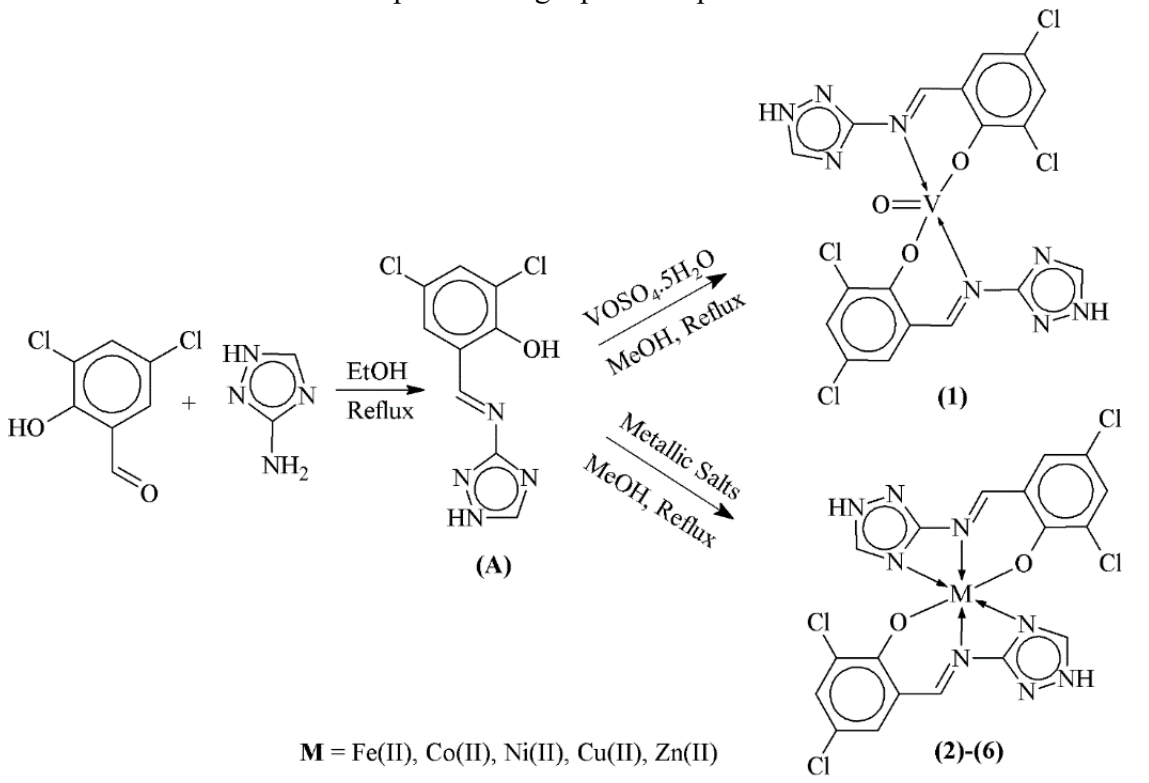

Scheme 1. Synthetic scheme of triazole ligand (A) and its metal complexes (1)-(6).

Bull. Chem. Soc. Ethiop. 2020, 34(2) 


\section{Biological activities}

All the newly synthesized metal based triazole complexes were evaluated for antibacterial, antifungal, antioxidant and antiglycation activities.

\section{In-vitro antibacterial activity}

The novel synthesized ligand (A) and its transition metal complexes were tested against four bacterial species (Staphylococcus aureus, Subtilis bacillus, Escherichia coli and Pseudomonas syringae) through disc diffusion method [20]. The materials used in antibacterial activity including nutrient broth, Petri-dishes and filter paper discs were autoclaved at $121{ }^{\circ} \mathrm{C}$ for 30 min. After heating the semi-liquid media of nutrient broth, it was poured into Petri plates and kept for solidification in fume hood, then the prepared inoculum was dispersed on solidified media by using glass loop spreader. Filter paper discs were kept on solidified bacterial inoculum after dipping from standard and samples. All the solutions were prepared in dimethyl sulfoxide (DMSO). Concentration of samples and standard solution was kept $5 \mathrm{mg} / \mathrm{mL}$. Augmentin syrup was used as standard drug because of its broad spectrum activity. After that, the Petri dishes were kept in incubator at $37^{\circ} \mathrm{C}$ and then the inhibition area was determined after 48 hours.

\section{In-vitro antifungal activity}

The antifungal activity of newly synthesized ligand (A) and its transition metal chelates was performed by using disc diffusion method [20] against two fungal strains (Alterneria alternate and Drechslera australensis). Terbicil capsule was used as standard drug. All the samples and standard solutions were prepared in DMSO by using micropipette. After keeping the Petri dishes in incubator at $37^{\circ} \mathrm{C}$ for 72 hours, the inhibition zones were noted.

\section{Antioxidant activity}

By using DPPH method, reducing power method and concentration of total phenolic content, anti-oxidant activity of synthesized compounds was determined.

\section{DPPH method}

Antioxidant activity of newly synthesized compounds was determined by adopting recommended procedure by using DPPH (1,1-diphenyl-2-picryl hydrazyl) [21]. The procedure was carried out by using different concentrations $(2 \mathrm{mg} / \mathrm{mL}$ and $1 \mathrm{mg} / \mathrm{mL})$ of sample solutions and $20 \mathrm{mg} / 100 \mathrm{~mL}$ solution of DPPH radical. The reaction mixture was prepared by mixing 1 $\mathrm{mL}$ of DPPH solution in $4 \mathrm{~mL}$ of methanol and $100 \mu \mathrm{L}$ of sample solution in test tubes. The tubes were wrapped with aluminum foil and kept in incubator $\left(37^{\circ} \mathrm{C}\right)$ for half an hour. Butylatedhydroxytoluene (BHT) was used as the standard. The absorption of synthesized compounds was measured at $517 \mathrm{~nm}$ and the percentage inhibition was calculated by using following formula:

Percentage $(\%)$ inhibition $=\frac{(\text { Blank-Sample })}{\text { Blank }} \times 100$

Reducing power method

Total antioxidant capability of triazole ligand and its metal complexes was determined by using standard procedure [22]. In this method, $1 \mathrm{~mL}$ sample solutions having concentration of 1 $\mathrm{mg} / \mathrm{mL}$ were tested. The sample solutions were prepared in pure DMSO and mixed with $2.5 \mathrm{~mL}$ of $2 \mathrm{M}$ sodium phosphate buffer having $\mathrm{pH} 6.6$ and $5 \mathrm{~mL}$ of $1 \%$ potassium ferricyanide. Then 
the reaction mixture was incubated at $50{ }^{\circ} \mathrm{C}$ for $30 \mathrm{~min}$. After that, $5 \mathrm{~mL}$ of $10 \%$ trichloroacetic acid was added and centrifuged at $1000 \mathrm{RPM}$ for $10 \mathrm{~min}$. After centrifugation, two separate layers were formed. From upper layer, $5 \mathrm{~mL}$ sample solution was taken and mixed with $5 \mathrm{~mL}$ of distilled water and $1 \mathrm{~mL}$ of $1 \%$ ferric chloride. At the end, absorbance was measured at $700 \mathrm{~nm}$ with the help of spectrophotometer.

\section{Concentration of total phenolic content}

The absorbance of total phenolic content of ligand and its transition complexes was checked by using standard procedure [23]. In this method, $0.1 \mathrm{~mL}$ of sample solutions having concentration $2 \mathrm{mg} / \mathrm{mL}$ was mixed with $2 \mathrm{~mL}$ of sodium carbonate $(7.5 \%), 1 \mathrm{~mL}$ of $10 \%$ Folin reagent and 4 $\mathrm{mL}$ of methanol in seven different test tubes (one test tube for ligand and six for complexes). Test tubes were vortexed for $30 \mathrm{~s}$ and kept the whole reaction mixture at $37^{\circ} \mathrm{C}$ for half an hour. Finally, after incubation, the absorbance was measured at $760 \mathrm{~nm}$ by UV-Vis spectrophotometer. Gallic acid was used as a standard in this procedure. Quantifications of the sample triplicate were made by using the standard calibration curve of the gallic acid. Measurement was carried out for triplicate samples for each complex.

Antiglycation activity of ligand and its metal complexes

In this method glucose working solution having $1 \mathrm{M}$ concentration was prepared in distilled water. A buffer was formed by using $3.56 \mathrm{~g}$ of di-sodium-hydrogen phosphate and $2.76 \mathrm{~g}$ of sodium-di-hydrogen phosphate in $100 \mathrm{~mL}$ of deionized water. In order to maintain the $\mathrm{pH}$ of buffer solution at 7.4; mixed the $38.5 \mathrm{~mL}$ of di-sodium-hydrogen phosphate with $11.5 \mathrm{~mL}$ of sodium-di-hydrogen phosphate. Similarly, $2 \mathrm{mg} / \mathrm{mL}$ solutions of BSA (bovine serum albumin), TCA (trichloro acetic acid) and rutin were prepared accordingly in distilled water. Rutin was used as standard. Three different solutions were prepared, i.e. positive (BSA + Buffer + Glucose), negative (BSA + Buffer) and standard (BSA + Rutin + Glucose). All the sample solutions were prepared in methanol with concentration of $2 \mathrm{mg} / \mathrm{mL}$. The reaction was carried out in small plastic tubes having $1 \mathrm{~mL}$ volume by using micropipette [24]. All the tubes were kept at $37{ }^{\circ} \mathrm{C}$ in an incubator for seven days. After seven days reaction was stopped by adding the $200 \mu \mathrm{L}$ solution of TCA having concentration of $2 \mathrm{mg} / \mathrm{mL}$ in each tube. Then centrifuge all the tubes at $8000 \mathrm{rpm}$ for $5 \mathrm{~min}$ in order to form the pellets. At the end, added $100 \mu \mathrm{L}$ buffers in each tube and the fluorescence results were checked by using nano-flourometer instrument. Excitation and emission wavelengths of nano-fluorometer were 330 and $440 \mathrm{~nm}$, respectively.

\section{Computational procedure}

Density functional theory (DFT) study of synthesized triazole compounds was performed using Gaussian program. The input files were recorded to use Gauss View [25]. Ultraviolet-visible analysis was performed in combination of B3LYP/6-311+g $(\mathrm{d}, \mathrm{p})$ in gas phase. Avogadro, Chemcraft and Gauss View softwares were used to check the output files [26].

\section{RESULTS AND DISCUSSION}

The condensation of 1H-1,2,4-triazole-3-amine with 3,5-dichlorosalicylaldehyde in an equimolar ratio resulted to form a new triazole Schiff base which was an air and moisture stable yellow colored solid compound. The synthesized ligand was soluble in methanol, ethanol, dioxane, DMSO and DMF at room temperature. The ligand readily reacted with salts of transition metals [VO(IV), $\mathrm{Fe}(\mathrm{II}), \mathrm{Co}(\mathrm{II}), \mathrm{Ni}(\mathrm{II}), \mathrm{Cu}(\mathrm{II})$ and $\mathrm{Zn}(\mathrm{II})$ ] in methanol to form their metal complexes by using ligand and metallic salt in 2:1 molar ratio, respectively. All the 
synthesized metal complexes were intensely colored except $\mathrm{Zn}(\mathrm{II})$ complex (6) that was colorless. The metal complexes decomposed without melting. The spectral data showed that the ligand coordinated with the metal ions in bidentate and tridentate manner via NO and NNO donor sites. The spectral data of the prepared ligand and its metal complexes shown in Table 1, was in good agreement with their structures indicating the high purity of all the compounds.

Table 1. Physical, analytical and elemental data of ligand (A) and metal complexes (1)-(6).

\begin{tabular}{|c|c|c|c|c|c|c|c|c|}
\hline \multirow[t]{2}{*}{ No } & \multirow[t]{2}{*}{ Compounds } & \multirow{2}{*}{$\begin{array}{l}\text { Yield (\%) } \\
\text { color }\end{array}$} & \multirow{2}{*}{$\begin{array}{l}\mathrm{M} . \mathrm{W}(\mathrm{g} / \mathrm{mol}) \\
\text { chemical formula }\end{array}$} & \multirow{2}{*}{$\begin{array}{l}\text { M.P } \\
\left({ }^{\circ} \mathrm{C}\right)\end{array}$} & \multicolumn{4}{|c|}{ Calculated \% (found) } \\
\hline & & & & & $\mathrm{C}$ & $\mathrm{H}$ & $\mathrm{N}$ & $\mathrm{M}$ \\
\hline (A) & Ligand & $\begin{array}{c}94 \\
\text { Pale yellow }\end{array}$ & $\begin{array}{c}{[257.08]} \\
\mathrm{C}_{9} \mathrm{H}_{6} \mathrm{Cl}_{2} \mathrm{~N}_{4} \mathrm{O}\end{array}$ & 231 & $\begin{array}{c}42.05 \\
(41.80)\end{array}$ & $\begin{array}{c}2.35 \\
(2.26)\end{array}$ & $\begin{array}{c}21.79 \\
(21.60)\end{array}$ & - \\
\hline (1) & $\mathrm{VO}(\mathrm{A})_{2}$ & $\begin{array}{c}76 \\
\text { Green }\end{array}$ & $\begin{array}{c}{[579.07]} \\
\mathrm{C}_{18} \mathrm{H}_{10} \mathrm{Cl}_{4} \mathrm{~N}_{8} \mathrm{O}_{3} \mathrm{~V}\end{array}$ & 236 & $\begin{array}{c}37.33 \\
(37.25)\end{array}$ & $\begin{array}{c}1.74 \\
(1.68)\end{array}$ & $\begin{array}{c}19.35 \\
(19.24)\end{array}$ & $\begin{array}{c}8.80 \\
(8.74)\end{array}$ \\
\hline$(2)$ & $\mathrm{Fe}(\mathrm{A})_{2}$ & $\begin{array}{c}89 \\
\text { Dark brown } \\
\end{array}$ & $\begin{array}{c}{[567.98]} \\
\mathrm{C}_{18} \mathrm{H}_{10} \mathrm{Cl}_{4} \mathrm{FeN}_{8} \mathrm{O}_{2} \\
\end{array}$ & 246 & $\begin{array}{c}38.06 \\
(38.01) \\
\end{array}$ & $\begin{array}{c}1.77 \\
(1.71) \\
\end{array}$ & $\begin{array}{c}19.73 \\
(19.64) \\
\end{array}$ & $\begin{array}{c}9.83 \\
(9.77) \\
\end{array}$ \\
\hline (3) & $\mathrm{Co}(\mathrm{A})_{2}$ & $\begin{array}{c}91 \\
\text { Gray }\end{array}$ & $\begin{array}{c}{[571.06]} \\
\mathrm{C}_{18} \mathrm{H}_{10} \mathrm{Cl}_{4} \mathrm{CoN}_{8} \mathrm{O}_{2}\end{array}$ & 252 & $\begin{array}{c}37.86 \\
(37.79) \\
\end{array}$ & $\begin{array}{c}1.77 \\
(1.72) \\
\end{array}$ & $\begin{array}{c}19.62 \\
(19.54)\end{array}$ & $\begin{array}{c}10.32 \\
(10.26) \\
\end{array}$ \\
\hline (4) & $\mathrm{Ni}(\mathrm{A})_{2}$ & $\begin{array}{c}86 \\
\text { Brown } \\
\end{array}$ & $\begin{array}{c}{[570.82]} \\
\mathrm{C}_{18} \mathrm{H}_{10} \mathrm{Cl}_{4} \mathrm{NiN}_{8} \mathrm{O}_{2}\end{array}$ & 290 & $\begin{array}{c}37.87 \\
(37.67) \\
\end{array}$ & $\begin{array}{c}1.77 \\
(1.73) \\
\end{array}$ & $\begin{array}{l}19.63 \\
(19.56)\end{array}$ & $\begin{array}{c}10.28 \\
(10.23)\end{array}$ \\
\hline (5) & $\mathrm{Cu}(\mathrm{A})_{2}$ & $\begin{array}{c}92 \\
\text { Dirty green }\end{array}$ & $\begin{array}{c}{[575.68]} \\
\mathrm{C}_{18} \mathrm{H}_{10} \mathrm{Cl}_{4} \mathrm{CuN}_{8} \mathrm{O}_{2}\end{array}$ & 240 & $\begin{array}{c}37.55 \\
(37.37) \\
\end{array}$ & $\begin{array}{c}1.75 \\
(1.71) \\
\end{array}$ & $\begin{array}{l}19.46 \\
(19.4) \\
\end{array}$ & $\begin{array}{c}11.04 \\
(10.97) \\
\end{array}$ \\
\hline (6) & $\mathrm{Zn}(\mathrm{A})_{2}$ & $\begin{array}{c}95 \\
\text { Off white }\end{array}$ & $\begin{array}{c}{[577.54]} \\
\mathrm{C}_{18} \mathrm{H}_{10} \mathrm{Cl}_{4} \mathrm{~N}_{8} \mathrm{O}_{2} \mathrm{Zn}\end{array}$ & 256 & $\begin{array}{r}37.43 \\
(37.24) \\
\end{array}$ & $\begin{array}{c}1.75 \\
(1.71) \\
\end{array}$ & $\begin{array}{c}19.40 \\
(19.35) \\
\end{array}$ & $\begin{array}{c}11.33 \\
(11.26) \\
\end{array}$ \\
\hline
\end{tabular}

${ }^{1} H$-NMR spectrum

${ }^{1}$ H-NMR spectrum of triazole Schiff base ligand (A) was recorded in DMSO solvent to determine the structural properties. The inspection of spectrum presented the representative peaks of $\mathrm{N}-\mathrm{H},(\mathrm{HC}=\mathrm{N})$ and $\mathrm{C}-\mathrm{H}$ protons of synthesized triazole compound at 14.29, 9.41 and $8.64 \mathrm{ppm}$, respectively as a singlet. Furthermore, two signals; doublets at 7.76 and $7.92 \mathrm{ppm}$ for aromatic protons in benzene ring were observed. Higher chemical shift values of these two protons were due to the attachment of more electronegative chloro group with neighbouring carbon atoms. The proton signal at $7.92 \mathrm{ppm}$ was due to $\mathrm{C}-\mathrm{H}$ groups which are in between the two chloro attached carbon atoms. The value of proton of $\mathrm{OH}$ group in ligand moved downfield and was observed at $13.85 \mathrm{ppm}$ due to the possibility of hydrogen bonding of oxygen atom and proton of azomethine carbon [27]. The examination of all observed signals confirmed the formation of triazole Schiff base ligand (A) and its proposed structure.

${ }^{13} \mathrm{C}-\mathrm{NMR}$ spectrum

${ }^{13} \mathrm{C}$-NMR spectrum of ligand was recorded in DMSO solvent. In ${ }^{13} \mathrm{C}$-NMR spectral data, all the numbers of carbon atoms were found in their expected regions. The ${ }^{13} \mathrm{C}$-NMR data showed the azomethine carbon $\left(\mathrm{C}_{13}\right)$ peak at $164.73 \mathrm{ppm}$ which confirmed the condensation reaction. Due to the possibility of hydrogen bonding between oxygen of $\mathrm{OH}$ group and proton of azomethine carbon, aromatic ring carbon $\left(\mathrm{C}_{8}\right)$ displayed peak at $133.30 \mathrm{ppm}$. Carbon atom $\left(\mathrm{C}_{1}\right)$ which is present between the two nitrogen atoms in triazole ring, exhibited peak at $145.18 \mathrm{ppm}$, from which confirmed the formation of ligand $(A)$. Furthermore $\left(C_{9}\right),\left(C_{10}\right),\left(C_{11}\right),\left(C_{12}\right)$ and $\left(C_{13}\right)$ exhibited their respective peaks at 131.56, 122.05, 123.29, 135.50 and 164.73 ppm, individually which are in close agreement to their experimental values and compromised well with the number of carbon atoms present in the proposed structure of ligand. 
Synthesis, structural, spectral and biological evaluation of metals endowed 1,2,4-triazole 341

Mass spectrum

The mass spectral data and fragmentation pattern of the triazole Schiff base ligand (A) intensely confirmed the formation of the ligand, its proposed structure along with its bonding pattern. It was concluded from the mass spectrum of the ligand that different peaks of various fragments from parent ligand molecule at different intensities gave the idea of molecular ion peak and base peaks of synthesized compound. The molecular ion peak was noted at mass to charge ratio $(\mathrm{m} / \mathrm{z})$ of 257.07 which indicated the formation of ligand. The base peak of most stable fragment of parent ligand molecule was observed at $\mathrm{m} / \mathrm{z}=180.17$. Fragmentation pattern of ligand resulted from the breakdown of $\mathrm{C}-\mathrm{N}, \mathrm{C}=\mathrm{N}, \mathrm{C}-\mathrm{O}, \mathrm{O}-\mathrm{H}, \mathrm{C}-\mathrm{Cl}$ and $\mathrm{C}-\mathrm{C}$.

IR spectra

The main IR vibrational bands of the triazole Schiff base and its metal complexes were found in their expected regions. IR spectrum of triazole ligand (A) confirmed the formation of new functional group, azomethine $(\mathrm{HC}=\mathrm{N})$ at $1640 \mathrm{~cm}^{-1}$ that strongly indicated the condensation reaction. Ligand also showed band at $3180 \mathrm{~cm}^{-1}$ due to the presence of $-\mathrm{OH}$ group [28]. The appearance of peaks at 1585,1380 and $1020 \mathrm{~cm}^{-1}$ indicated the presence of $\mathrm{C}=\mathrm{N}$ of triazole, $\mathrm{C}-\mathrm{O}$ and N-N groups, respectively [29]. There was a close agreement between both values of experimental results taken from IR spectrum and theoretically computed data from IR spectrum of ligand. After complex formation, band of azomethine vibration at $1640 \mathrm{~cm}^{-1}$ shifted to 1620 $1625 \mathrm{~cm}^{-1}$ thus indicating the coordination of the azomethine- $\mathrm{N}$ to the transition metals $(\mathrm{V}, \mathrm{Fe}$, $\mathrm{Co}, \mathrm{Ni}, \mathrm{Cu}, \mathrm{Zn}$ ) [30]. Similarly, band of $\mathrm{C}-\mathrm{O}$ at $1380 \mathrm{~cm}^{-1}$ was shifted to1355-1360 $\mathrm{cm}^{-1}$ and disappearance of $\mathrm{OH}$ band at $3180 \mathrm{~cm}^{-1}$ hence confirming the deprotonation and coordination of salicylidene- $\mathrm{OH}$ [31]. On the other hands, there was no shifting of N-N and N-H bands showing their non-involvement in the coordination [32] and confirmed the proposed structures of the metal complexes.

\section{Molar conductance and magnetic moment measurements}

The concentration of $0.01 \mathrm{M}$ solution of DMF was used to determine the molar conductance of synthesized metal complexes by using Inolab Cond 720 Conducto-meter at room temperature. The conductance values were observed in the range of $12-20 \Omega^{-1} \mathrm{~cm}^{2} \mathrm{~mol}^{-1}$, hence confirming the non-electrolytic nature of the metal complexes [33]. The magnetic moments of newly synthesized compounds were determined by using Gouy balance. Some of compounds showed high magnetic moments while some showed low magnetic moments depending upon the magnetic power of unpaired and paired electrons. VO(IV) complexes exhibited magnetic moment value of $4.42 \mathrm{BM}$ that was indicative of one unpaired electron, and supporting its square-pyramidal geometry. Magnetic moment values of $\mathrm{Cu}(\mathrm{II})$ and $\mathrm{Fe}$ (II) complexes were found to be 1.75 and 5.59 BM [19], which indicated the presence of one and four unpaired electrons of copper and iron, respectively. Both complexes showed octahedral geometry which is most stable. Co(II) complex exhibited the magnetic moment value of $4.39 \mathrm{BM}$ that clued the presence of three unpaired electrons and octahedral geometry of the complex. The measured magnetic moment value of $\mathrm{Ni}$ (II) complex was found to be $3.60 \mathrm{BM}$ which confirmed the presence of two unpaired electrons and octahedral geometry of the complex. Zn(II) did not show magnetic moment value indicating the diamagnetic nature of the zinc complex [34].

\section{Natural bond orbital (NBO) analysis}

The NBO analysis of ligand (A) was done by using B3LYP/6-311+g(d,p) method to determine the perturbation theory. The data obtained from NBO analysis was helpful to find the 
conjugation as well as the interaction of charge transfer in the molecule. The interactions between contributors and acceptors gave massive amount of stabilization energy. Strength of electron donors and electron acceptors was easily affected by stabilization energy, which was achieved by using NBO analysis [35]. A lot of information was obtained from calculations of ligand by using NBO analysis, here just promising transitions are explained which contain higher value of stability. The conjugation of the entire framework can also be explained on the basis of second-order stabilization energy. The stabilization energy $E^{(2)}$ is determined by equation;

$$
E^{(2)}=q i \frac{\left(F_{i . j}\right)^{2}}{\varepsilon_{j}-\varepsilon_{i}}
$$

where $\mathrm{q}_{\mathrm{i}}$, is the contributor orbital occupancy, $\mathrm{F}(i, j)$ is the off diagonal NBO Fock matrix element whereas, $\varepsilon_{j}$ and $\varepsilon_{i}$ are the diagonal elements, respectively. NBO study exhibited bunch of intra-molecular charge transfer (ICT) interactions. The charge transformations take place between different atoms. The prominent atoms in which charge interactions take place are; $\pi\left(\mathrm{C}_{5}\right.$ $\left.-\mathrm{C}_{6}\right) \rightarrow \pi^{*}\left(\mathrm{C}_{1}-\mathrm{C}_{2}\right), \pi\left(\mathrm{C}_{5}-\mathrm{C}_{6}\right) \rightarrow \pi^{*}\left(\mathrm{C}_{3}-\mathrm{C}_{4}\right)$ and $\pi\left(\mathrm{C}_{1}-\mathrm{C}_{2}\right) \rightarrow \pi^{*}\left(\mathrm{C}_{5}-\mathrm{C}_{6}\right)$ have higher stabilization energies $52.57,44.68$ and $5.729 \mathrm{kcal} / \mathrm{mol}$, respectively as compared to other atoms present in the molecule. The assignment of charge between the lone pairs are; $\mathrm{O}_{12} \rightarrow \sigma^{*}\left(\mathrm{C}_{3}-\right.$ $\left.\mathrm{H}_{4}\right), \mathrm{Cl}_{15} \rightarrow \sigma^{*}\left(\mathrm{C}_{1}-\mathrm{C}_{2}\right), \mathrm{N}_{17} \rightarrow \pi^{*}\left(\mathrm{~N}_{19}-\mathrm{C}_{20}\right)$, leads higher stabilization energies 4.073, 2.909, $1.240 \mathrm{kcal} / \mathrm{mol}$, respectively as compared to that of other atoms which contain lone pairs. All the shown conjugated interactions of different atoms show charge transformations among each other. The calculated NBO analysis exhibited high interactions of atoms with each other, explaining the stability of compound and gave an authentic idea about the stabilization energy.

\section{Mulliken atomic charges (MAC) analysis}

Mulliken atomic charge analysis is a significant portion in quantum chemistry to determine the chemical action in molecular structure; as the atomic charges are highly affected by electronic configuration, their polarity and characteristics of molecules [36]. The Mulliken atomic charges of ligand (A) were determined by using B3LYP/6-311+g(d,p). The measured values of atomic charges exhibited the presence of highly electronegative atoms such as $(12 \mathrm{O}=-0.247337),(17$ $\mathrm{N}=-0.155209),(18 \mathrm{~N}=-0.175012)$ and $(19 \mathrm{~N}=-0.088723)$ from which it is clear that positive charge is distributed on the carbon atoms while all types of hydrogen atoms possess positive charge. Histogram of Mulliken atomic charges is given in Figure 1.

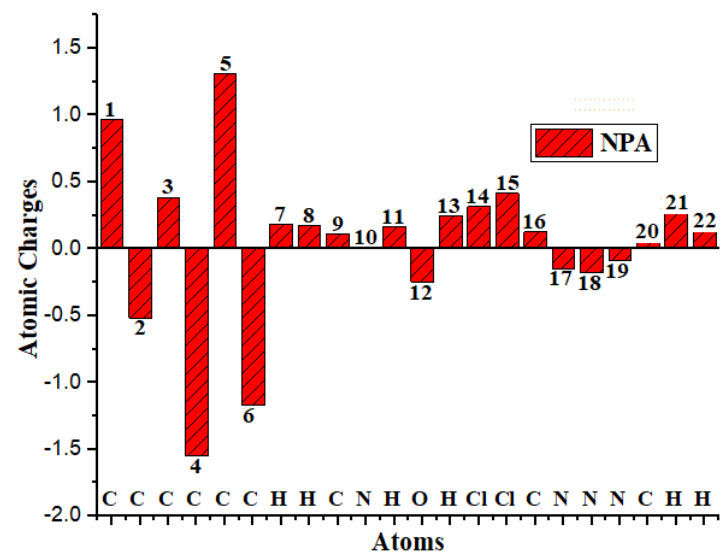

Figure 1. Histogram for Mulliken atomic charge distribution of the ligand (A).

Bull. Chem. Soc. Ethiop. 2020, 34(2) 


\section{Experimental FT-IR results of ligand}

The resulted experimental and computational data of ligand (A) including its intensity and vibrations is given in Table 2. Theoretical study was carried out by B3LYP/6-311+g(d,p) basis set and results were in close agreement with experimental band of IR.

Table 2. Experimental and theoretical frequencies of FT-IR for ligand (A).

\begin{tabular}{|c|c|c|l|}
\hline Frequency scaled & Experimental & $\mathrm{I}_{\text {IR }}$ & Vibrational assignments \\
\hline 726.5050 & 730 & 19.9516 & $v(\mathrm{~s}) \mathrm{C}-\mathrm{Cl}_{\text {aliphatic }}$ \\
\hline 759.6710 & & 07.0719 & $v(\mathrm{~s}) \mathrm{C}-\mathrm{Cl}_{\text {aliphatic }}+\mathrm{C}-\mathrm{C}_{\text {aromatic }}$ \\
\hline 820.6385 & 830 & 12.6818 & $v(\mathrm{~s}) \mathrm{C}-\mathrm{N}_{\text {aromatic }}$ \\
\hline 838.6090 & 850 & 17.0374 & $\rho(\mathrm{s}) \mathrm{C}-\mathrm{H}_{\text {aromatic }}$ \\
\hline 860.4536 & & 13.4856 & $\rho(\mathrm{s}) \mathrm{C}-\mathrm{H}_{\text {aromatic }}+\rho(\mathrm{b}) \mathrm{C}-\mathrm{C}_{\text {aromatic }}$ \\
\hline 1115.4025 & 1100 & 115.5129 & $v(\mathrm{~s}) \mathrm{C}-\mathrm{O}_{\text {aliphatic }}$ \\
\hline 1177.4153 & 1195 & 23.1238 & $v(\mathrm{~s}) \mathrm{C}-\mathrm{O}_{\text {aliphatic }}+\mathrm{O}-\mathrm{H}_{\text {aliphatic }}$ \\
\hline 1269.6629 & & 12.9349 & $(v) \mathrm{C}-\mathrm{OH}_{\text {aliphatic }}$ \\
\hline 1292.7173 & & 38.5510 & $(v) \mathrm{C}-\mathrm{OH}_{\text {aliphatic }}$ \\
\hline 1330.5198 & 1330 & 23.7137 & $v(\mathrm{~s}) \mathrm{C}-\mathrm{N}_{\text {aromatic }}$ \\
\hline 1392.4886 & & 17.4504 & $v($ as $) \mathrm{C}-\mathrm{N}_{\text {aromatic }}$ \\
\hline 1428.5505 & 1450 & 138.5775 & $v(\mathrm{~s}) \mathrm{C}-\mathrm{C}_{\text {aromatic }}$ \\
\hline 1482.7146 & & 14.2577 & $v(\mathrm{~s}) \mathrm{C}-\mathrm{C}_{\text {aromatic }}+v($ as $) \mathrm{C}-\mathrm{C}_{\text {aromatic }}$ \\
\hline 1588.7302 & 1600 & 26.5723 & $v(\mathrm{v}) \mathrm{C}=\mathrm{N}_{\text {aromatic }}$ \\
\hline 1603.4793 & & 35.6012 & $v($ as $) \mathrm{C}=\mathrm{N}_{\text {aromatic }}$ \\
\hline 3325.0352 & 3400 & 07.3995 & $v(\mathrm{~s}) \mathrm{N}-\mathrm{H}_{\text {aromatic }}$ \\
\hline 3338.6076 & & 00.9429 & $v($ as $) \mathrm{N}-\mathrm{H}_{\text {aromatic }}$ \\
\hline
\end{tabular}

$v=$ stretching, $\rho=$ rocking, $\mathrm{b}=$ bending, $\mathrm{s}=$ symmetric, as = asymmetric. Intensity (I) in $\mathrm{kJ} / \mathrm{mol}$ and frequency (v) in $\mathrm{cm}^{-1}$.

\section{UV-Visible analysis}

UV-Visible spectral study for ligand (A) was performed by using time dependent density fractional theory (TD-DFT) in the gas phase using B3LYP/6-311+g(d,p) to explain the characteristics of vertical electronic transitions [19]. Two transitions of electrons were obtained at 328.5 and $273 \mathrm{~nm}$ having oscillator strength of 0.1186 and 0.0006 respectively that are very close to experimental variation values 328 and $291 \mathrm{~nm}$, respectively.

Frontier molecular orbital (FMO) analysis

The stability, electrical properties and reactivity of any compound can be determined by energy difference of frontier molecular orbitals [37]. The highest occupied molecular orbitals (HOMO) and lowest unoccupied molecular orbitals (LUMO) behave as electron donors and the electron acceptors, respectively. Furthermore, electronic excitations that take place from HOMO to LUMO of ligand (A) areas illustrated in Figure 2. The data obtained from DFT calculations showed that the ligand (A) exhibited 403 orbitals, from which the numbers of HOMO and LUMO orbitals were 65 and 66, respectively. The appearance of golden color indicates the positive and blue color indicates the negative part of orbitals. The energy values of HOMO and LUMO orbitals obtained from DFT study were -6.966 and $-2.621 \mathrm{eV}$, respectively. Furthermore, energy values of HOMO-1 and LUMO+1 were -7.248 and $-1.225 \mathrm{eV}$, respectively. In the similar way $-7.805 \mathrm{eV}$ energy was found for HOMO-2 and $-1.054 \mathrm{eV}$ was found as the energy of LUMO+2. While the energies of HOMO-3 and LUMO+3 were obtained as $-8.050 \mathrm{eV}$ and $0.732 \mathrm{eV}$, respectively. The energy differences were $4.345,6.023,6.751$ and $7.318 \mathrm{eV}$ for $\mathrm{HOMO} \rightarrow$ LUMO; HOMO-1 $\rightarrow$ LUMO+1; HOMO-2 $\rightarrow$ LUMO+2 and HOMO-3 $\rightarrow$ LUMO+3, respectively. 


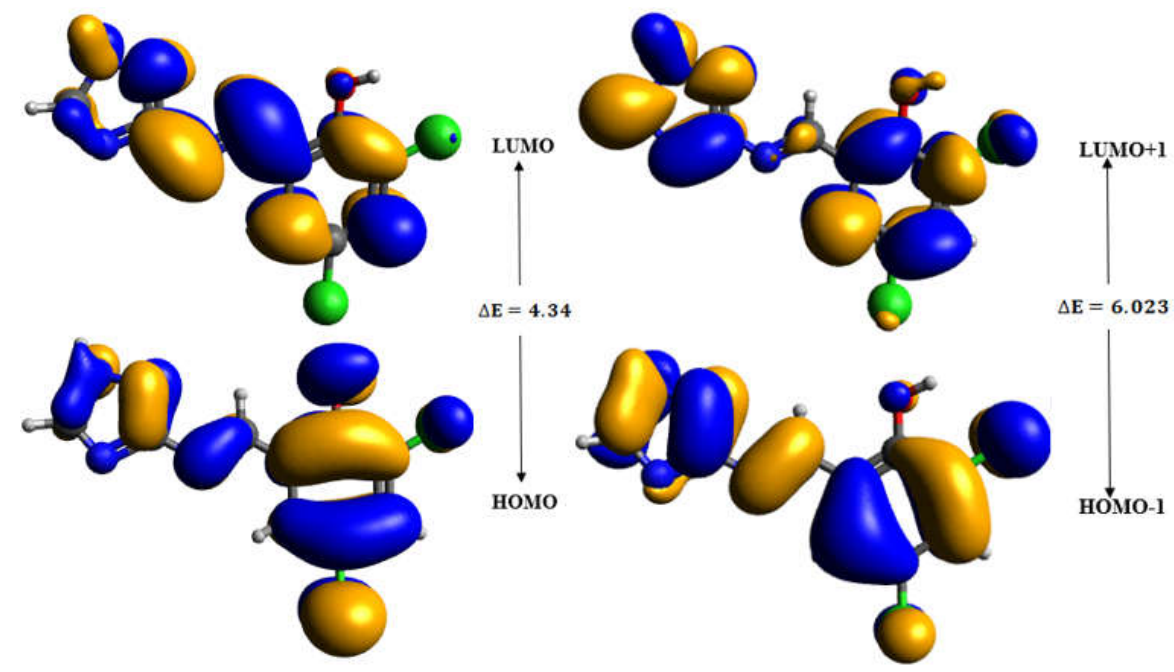

Figure 2. Frontier molecular orbitals of the ligand (A).

\section{Global reactivity descriptors}

The energies of HOMO and LUMO are used to gain insight into the promising global reactivity descriptors and summarized in Table 3. Koopmans's theorem has been used to determine the electronegativity $(\chi)$, chemical hardness $(\eta)$ and chemical potential $(\mu)$ [38], which are defined from the following equations as;

$\mathrm{IP}=-\mathrm{E}_{\text {HOMO }}$

$\mathrm{EA}=-\mathrm{E}_{\mathrm{LUMO}}$

$x=\frac{[\mathrm{IP}+\mathrm{EA}]}{2}=-\frac{E_{L U M O}+E_{H O M O}}{2}$

$\eta=\frac{[\mathrm{IP}-\mathrm{EA}]}{2}=-\frac{E_{L U M O}-E_{H O M O}}{2}$

$\mu=\frac{E_{L U M O}+E_{H O M O}}{2}$

where IP = ionization potential (a.u), EA = electron affinity (au).

Global softness $(\sigma)$ is defined by following relationship;

$\sigma=\frac{1}{2} \eta$

And electrophilicity index $(\omega)$ can be defined by below equation;

$\omega=\frac{\mu^{2}}{2 \eta}$

This parameter is considered as a measure of the electrophilic strength of a compound. Electronegativity $(\chi)$ has been defined as negative of the chemical potential. Usually, the chemical behavior of any species can be evaluated with the help of global softness, global hardness, electronegativity and chemical potential parameters. Molecules containing small energy gap are recognized as soft compounds and the molecules which contain large energy gap, are recognized as hard compounds with less chemical reactivity and greater kinetic 
stability. In the current study, the larger magnitude of ionization potential is observed, which suggests high reactivity of the title molecule (A). The value of softness is higher as compared to that of hardness, suggesting its high reactivity and less stability (Table 3). However, the molecule has the negative value of chemical potential. On the basis of the obtained information, it can be concluded that the molecule might be highly reactive and reasonably stable.

Table 3. Ionization potential (I), electron affinity (A), electronegativity $(\chi)$, chemical hardness $(\eta)$, chemical potential $(\mu)$, global softness $(\sigma)$ and electrophilicity index $(\omega)$.

\begin{tabular}{|l|c|c|c|c|}
\hline Combinations & A & B & C & D \\
\hline Ionization potential $(\mathrm{I})$ & 6.967 & 7.249 & 7.805 & 8.050 \\
\hline Electron affinity $(\mathrm{A})$ & 2.622 & 1.225 & 1.055 & 0.732 \\
\hline Electronegativity $(\chi)$ & 4.794 & 4.230 & 4.430 & 4.394 \\
\hline Chemical hardness $(\eta)$ & 2.217 & 3.012 & 3.375 & 3.659 \\
\hline Chemical potential $(\mu)$ & -4.794 & -4.230 & -4.430 & -4.391 \\
\hline Global softness $(\sigma)$ & 0.225 & 0.166 & 0.148 & 0.136 \\
\hline Electrophilicity index $(\omega)$ & 5.180 & 2.970 & 2.907 & 2.634 \\
\hline
\end{tabular}

$\mathrm{A}=\mathrm{HOMO} \rightarrow \mathrm{LUMO}, \mathrm{B}=\mathrm{HOMO}-1 \rightarrow \mathrm{LUMO}+1, \mathrm{C}=\mathrm{HOMO}-2 \rightarrow \mathrm{LUMO}+2, \mathrm{D}=\mathrm{HOMO}-3 \rightarrow \mathrm{LUMO}+3$; units in $\mathrm{eV}$.

\section{Molecular electrostatic potential (MEP) analysis}

Molecular electrostatic potential (MEP) chart symbolizes the three-dimensional distribution of charge magnitude of a molecule. MEP is used to determine the interaction of charge transfer in single atom with each other. It is recognized as a helpful factor, which illustrates the shape, size, negative, positive zone without charge of an inspected system, which is generally assessed with standard shading. In terms of charge distribution, the order of code colors is: red $>$ orange $>$ yellow $>$ green $>$ blue. For that reason, the red region can be the favored destination for electrophilic attack whereas the blue region can be the favored destination for nucleophilic attack. The experimental data and computational theories can be used to determine the MEP, because it is known as one of the significant physical properties [32]. In Figure 3, all the hydrogen atoms of ligand (A) having blue color, suggest the comparative nonattendance of the electrons around hydrogen atoms. On the other hand, the more electronegative atoms like oxygen and nitrogen having red color show comparatively more magnitude of electron density, subsequently, it can be proved as a favored site for encounter of electrophilic attack.

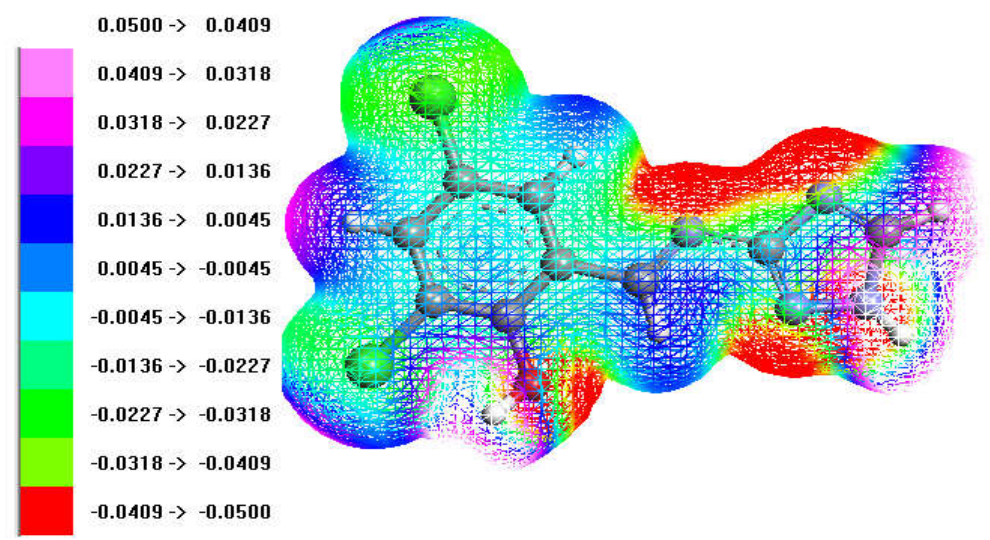

Figure 3. The molecular electrostatic potential for ligand.

Bull. Chem. Soc. Ethiop. 2020, 34(2) 
In-vitro antibacterial activity

Antibacterial activity of triazole based ligand and its transition metal complexes was checked against four types of bacterial strains, two Gram-positive (Subtilis bacillus and Staphylococcus aureus) and two Gram-negative (Pseudomonas syringae and Escherichia coli). The inhibition zones (millimeter) of ligand and its metal complexes were checked by comparing with the inhibition zone of amoxicillin which was used as standard drug. The results of all compounds and standard drug are shown in Table 4 and Figure 4. Amoxicillin exhibited greater inhibition as compared to other newly synthesized compounds. It was also concluded from results that ligand (A) showed less activity as compared to standard drug (amoxicillin) but comparably exhibited higher inhibition than metal complexes. Among metal chelates, zinc complex showed highest inhibition against Gram negative bacteria (Pseudomonas syringae and Escherichia coli), copper complex exhibited highest activity against Bacillus subtilis. Furthermore, complexes of copper and cobalt showed highest inhibition against Staphylococcus aureus as compared to other metal chelates [39].

Table 4. Antibacterial and antifungal activities of ligand and its metal complexes.

\begin{tabular}{|c|c|c|c|c|c|c|}
\hline \multirow{2}{*}{$\begin{array}{c}\text { Compound } \\
\text { No. }\end{array}$} & \multicolumn{3}{|c|}{ Bacterial strains } & \multicolumn{2}{c|}{ Fungal strains } \\
\cline { 2 - 7 } & $\begin{array}{c}\text { Subtilis } \\
\text { bacillus }\end{array}$ & $\begin{array}{c}\text { Pseudomonas } \\
\text { syringae }\end{array}$ & $\begin{array}{c}\text { Escherichia } \\
\text { coli }\end{array}$ & $\begin{array}{c}\text { Staphylococcus } \\
\text { aureus }\end{array}$ & $\begin{array}{c}\text { Alterneria } \\
\text { alternate }\end{array}$ & $\begin{array}{c}\text { Drechslera } \\
\text { australensis }\end{array}$ \\
\hline$(\mathrm{A})$ & 15 & 13.5 & 08 & 07 & 15 & 10 \\
\hline $\mathrm{VO}(\mathrm{A})_{2}$ & 08 & 09 & 05 & 08 & 19 & 09 \\
\hline $\mathrm{Fe}(\mathrm{A})_{2}$ & 05 & 07 & 00 & 06 & 05 & 14 \\
\hline $\mathrm{Co}(\mathrm{A})_{2}$ & 07 & 08 & 08 & 08 & 07 & 08 \\
\hline $\mathrm{Ni}(\mathrm{A})_{2}$ & 05 & 05 & 04 & 05 & 13 & 07 \\
\hline $\mathrm{Cu}(\mathrm{A})_{2}$ & 08 & 07 & 06 & 08 & 10 & 07 \\
\hline $\mathrm{Zn}(\mathrm{A})_{2}$ & 07 & 10 & 13 & 08 & 17 & 05 \\
\hline $\mathrm{DMSO}$ & - & - & - & - & - & - \\
\hline $\mathrm{SD}$ & 25 & 22 & 21 & 21 & 23 & 22 \\
\hline
\end{tabular}

Antibacterial and Antifungal Activity Comparison

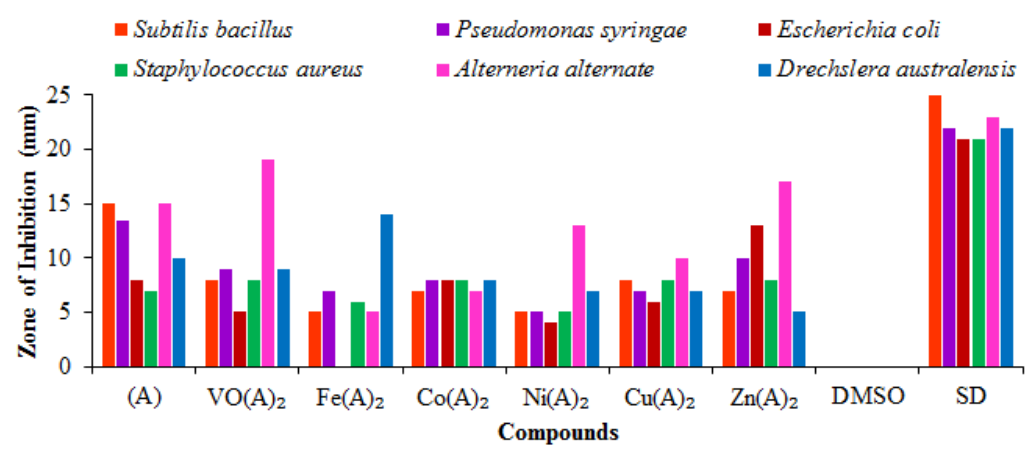

Figure 4. Antibacterial and antifungal activities of Schiff base ligand and metal complexes.

In-vitro antifungal activity

The antifungal activity of newly synthesized ligand (A) and its transition metal chelates was performed by using disc diffusion method against two fungal strains (Alterneria alternate, Drechslera australensis). The inhibition zones ( $\mathrm{mm}$ ) of ligand and its metal complexes were 
checked by comparing with terbicil, which was used as standard drug. The results of inhibition zones $(\mathrm{mm})$ of all the synthesized compounds and standard drug are presented in Table 4 and Figure 4. Overall triazole ligand displayed significant results against both fungal strains. Among the metal complexes, vanadium and zinc complexes possessed highest inhibition against Alterneria alternate. However, all the complexes were active against both fungal strains.

\section{In-vitro antioxidant activity}

The synthesized compounds showed antioxidant activity which was checked by using DPPH radical scavenging, reducing power method and concentration of total phenolic content.

\section{DPPH Method}

The diphenylpicrylhydrazide (DPPH) is free radical and have ability to check out the potency of radical scavenging of triazole ligand and it transition metal chelates. Two sample concentrations $(1 \mathrm{mg} / \mathrm{mL}$ and $2 \mathrm{mg} / \mathrm{mL})$ were used to check the antioxidant activity of triazole ligand and its metal chelates. Butylatedhydroxytoluene (BHT) was used as standard. Results showed that among $1 \mathrm{mg} / \mathrm{mL}$ sample concentrations, nickel complex exhibited [40] highest $(52.62 \%)$ and iron complex showed lowest (8.04\%) activity. While among $2 \mathrm{mg} / \mathrm{mL}$ sample concentrations, zinc complex showed highest (18.85\%) and copper complex exhibited lowest (10.32\%) activity as depicted in Table 5 and Figure 5.

Table 5. Antioxidant and antiglycationactivity results of ligand (A) and metal complexes.

\begin{tabular}{|c|c|c|c|c|c|c|}
\hline \multirow{2}{*}{$\begin{array}{c}\text { Comp- } \\
\text { ound }\end{array}$} & \multicolumn{5}{|c|}{ Antioxidant Activity } & $\begin{array}{c}\text { Antiglycation } \\
\text { activity }\end{array}$ \\
\cline { 2 - 7 } & $\begin{array}{c}\text { DPPH method } \\
(2 \mathrm{mg} / \mathrm{mL})\end{array}$ & $\begin{array}{c}\text { Reducing power } \\
(1 \mathrm{mg} / \mathrm{mL})\end{array}$ & $\begin{array}{c}\text { Total phenolic contents } \\
(\mathrm{nm})\end{array}$ & $\begin{array}{c}\text { Absorb- } \\
\text { ance }(\mathrm{nm})\end{array}$ & $\begin{array}{c}\text { Concentrations } \\
(\mathrm{ppm})\end{array}$ & $\begin{array}{c}\% \text { activity } \\
\end{array}$ \\
\hline $\mathrm{A}$ & 17.53 & 20.27 & 0.25 & 0.56 & 468 & 84.98 \\
\hline $\mathrm{VO}(\mathrm{A})_{2}$ & 16.38 & 40.92 & 1.68 & 0.39 & 304 & 83.54 \\
\hline $\mathrm{Fe}(\mathrm{A})_{2}$ & 17.32 & 08.04 & 0.37 & 0.36 & 267 & 82.62 \\
\hline $\mathrm{Co}(\mathrm{A})_{2}$ & 19.18 & 16.95 & 0.79 & 0.34 & 247 & 83.85 \\
\hline $\mathrm{Ni}(\mathrm{A})_{2}$ & 15.71 & 52.62 & 0.25 & 0.29 & 203 & 69.79 \\
\hline $\mathrm{Cu}(\mathrm{A})_{2}$ & 10.32 & 46.95 & 0.33 & 0.79 & 693 & 75.04 \\
\hline $\mathrm{Zn}(\mathrm{A})_{2}$ & 18.85 & 44.83 & 0.18 & 0.35 & 269 & 63.68 \\
\hline $\mathrm{Standard}$ & 64.38 & 55.56 & - & - & - & 88.19 \\
\hline
\end{tabular}

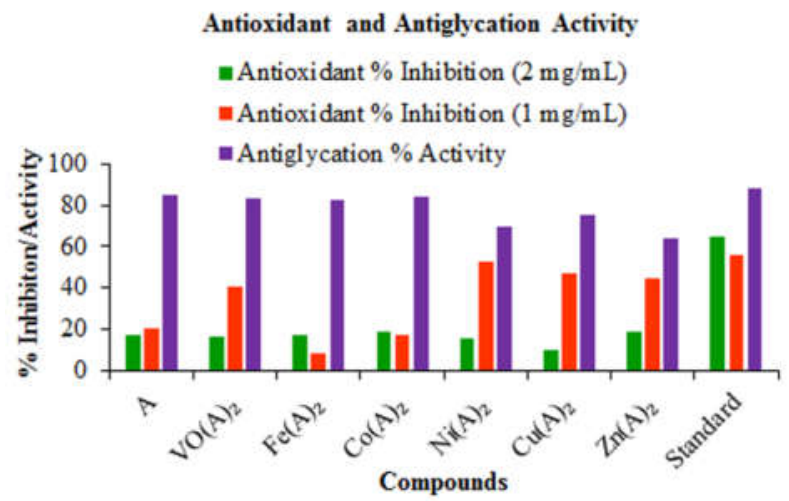

Figure 5. Antioxidant and antiglycation activities of ligand and its metal complexes. 


\section{Reducing power method}

Total antioxidant capability of triazole Schiff base and its metal complexes was determined. The results revealed that all the transition metal complexes exhibited high absorbance than that of their parent compound except zinc complex, which displayed least $(0.18 \mathrm{~nm})$ absorbance and vanadyl complex experienced highest absorbance of $1.68 \mathrm{~nm}$ (Table 5).

\section{Concentration of total phenolic content}

Concentrations of total phenolic contents of the ligand and its transition metal complexes were studied by UV-Vis spectrophotometer. Results were measured in absorbance and concentrations. The triazole ligand has more promising results as compared to metal complexes except copper complex which has shown better results out of the metal complexes (Table 5).

Antiglycation activity of ligand and its metal complexes

Antiglycation activity of synthesized ligand and its metal complexes was determined by using standard reported method. The triazole ligand and its complexes demonstrated promising results as shown in (Figure 5 and Tables 5). The triazole ligand displayed highest activity of $84.98 \%$ and cobalt complex possessed maximum activity $83.85 \%$ while zinc complex showed lowest activity of $63.68 \%$.

\section{CONCLUSION}

In this study, we have reported the synthesis of a newly synthesized triazole ligand, 2,4dichloro-6-[(1H-1,2,4-triazol-3-ylimino)methyl]phenol (A) along with its VO(IV), Fe(II), $\mathrm{Co}(\mathrm{II}), \mathrm{Ni}(\mathrm{II}), \mathrm{Cu}(\mathrm{II})$ and $\mathrm{Zn}(\mathrm{II})$ complexes. Synthesized compounds were characterized by physical, spectroscopic and elemental analysis. The results of DFT study of ligand displayed very close relationship between experimental values obtained from IR, UV and computed data obtained theoretically. All the compounds were assessed for their antimicrobial, antioxidant and antiglycation properties. Results of these activities showed that complexes have higher biological activities than that of parent ligand molecule. Finally, these promising results are helpful in different biological applications in the future endeavors.

\section{ACKNOWLEDGEMENT}

The authors are thankful to the Higher Education Commission (HEC) of Pakistan for providing financial support through the NRPU Project \# 7800.

\section{REFERENCES}

1. Abou-Hussein, A.A.; Linert, W. Synthesis, spectroscopic, coordination and biological activities of some organometallic complexes derived from thio-Schiff base ligands. Spectrochim. Acta A Mol. Biomol. Spectrosc. 2014, 117, 763-771.

2. Kajal, A.; Bala, S.; Kamboj, S.; Sharma, N.; Saini, V. Schiff bases: A versatile pharmacophore. J. Catal. 2013, 2013, 1-14.

3. Barwiolek, M.; Szlyk, E.; Surdykowski, A.; Wojtczak, A. New nickel(II) and copper(II) complexes with unsymmetrical Schiff bases derived from $(1 \mathrm{R}, 2 \mathrm{R})(-)$ cyclohexanediamine and the application of $\mathrm{Cu}(\mathrm{II})$ complexes for hybrid thin layers deposition. Dalton Trans. 2013, 42, 11476-11487.

4. Luo, X.Q.; Liu, Q.R.; Han, Y.J.; Xue, L.W. Vanadium complexes derived from fluorosubstituted Schiff bases: Synthesis, crystal structures, and antimicrobial activity. Inorg. Nano-Met. Chem. 2020, 50, 836-841. 
Synthesis, structural, spectral and biological evaluation of metals endowed 1,2,4-triazole 349

5. Malik, S.; Ghosh, S.; Mitu, L. Complexes of some $3 d$-metals with a Schiff base derived from 5-acetamido-1,3,4-thiadiazole-2-sulphonamide and their biological activity. J. Serb. Chem. Soc. 2011, 76, 1387-1394.

6. García-Valverde, M.; Torroba, T. Sulfur-nitrogen heterocycles. Molecules 2005, 10, 318320.

7. Dharsini, G.P.; Thanaraj, C.; Velladurai, R. Metal chelates of tridentate (NNO) 1,2,4triazine Schiff base: Synthesis, physico-chemical investigation and pharmacological screening. J. Inorg. Organomet. Polym. Mater. 2020, 30, 2315-2322.

8. Abu-Dief, A.M.; Abdel-Rahman, L.H.; Abdel-Mawgoud, A.A.H. A robust in vitro anticancer, antioxidant and antimicrobial agents based on new metal-azomethine chelates incorporating $\mathrm{Ag}(\mathrm{I}), \mathrm{Pd}(\mathrm{II})$ and $\mathrm{VO}(\mathrm{II})$ cations: Probing the aspects of DNA interaction. Appl. Organomet. Chem. 2020, 34, 1-20.

9. Tacconelli, E.; Carrara, E.; Mendelson, M.; Monnet, D.L.; Pulcini, C.; Kluytmans, J.; Carmeli, Y.; Ouellette, M.; Outterson, K.; Patel, J.; Cavaleri, M.; Cox, E.M.; Houchens, C.R.; Grayson, M.L.; Hansen, P.; Zorzet, A. Discovery, research, and development of new antibiotics: The WHO priority list of antibiotic-resistant bacteria and tuberculosis. Lancet Infect. Dis. 2018, 18, 318-327.

10. Bouhidel, Z.; Cherouana, A.; Durand, P.; Doudouh, A.; Morini, F.; Guillot, B.; Dahaoui, S. Synthesis, spectroscopic characterization, crystal structure, Hirshfeld surface analysis and antimicrobial activities of two triazole Schiff bases and their silver complexes. Inorg. Chim. Acta 2018, 482, 34-47.

11. Gichumbi, J.M.; Friedrich, H.B.; Omondi, B.; Lazarus, G.G.; Singh, M.; Chenia, H.Y. Synthesis, characterization, anticancer and antimicrobial study of arene ruthenium(II) complexes with 1,2,4-triazole ligands containing an $\alpha$-diimine moiety. Z. Naturforsch. $B$. 2018, 73, 167-178.

12. Hanif, M.; Chohan, Z.H. Synthesis, spectral characterization and biological studies of transition metal(II) complexes with triazole Schiff bases. Appl. Organomet. Chem. 2013, 27 , 36-44.

13. Lazić, J.M.; Vučićević, L.; Grgurić-Šipka, S.; Janjetović, K.; Kaluđerović, G.N.; Misirkić, M.; Gruden-Pavlović, M.; Popadić, D.; Paschke, R.; Trajković, V. Synthesis and in vitro anticancer activity of octahedral platinum(IV) complexes with cyclohexyl-functionalized ethylenediamine-N,N'-diacetate-type ligands. ChemMedChem 2010, 5, 881-889.

14. Khalil, M.M.; Ismail, E.H.; Mohamed, G.G.; Zayed, E.M.; Badr, A., Synthesis and characterization of a novel Schiff base metal complexes and their application in determination of iron in different types of natural water. Open J. Inorg. Chem. 2012, 2, $13-$ 21.

15. Calu, L.; Badea, M.; Korošin, N.Č.; Chifiriuc, M.C.; Bleotu, C.; Stanică, N.; Silvestro, L.; Maurer, M.; Olar, R. Spectral, thermal and biological characterization of complexes with a Schiff base bearing triazole moiety as potential antimicrobial species. J. Therm. Anal. Calorim. 2018, 134, 1839-1850.

16. Munawar, K.; Ali, S.; Tahir, M.; Khalid, N.; Abbas, Q.; Qureshi, I.; Shahzadi, S. Investigation of derivatized Schiff base ligands of 1,2,4-triazole amine and their oxovanadium(IV) complexes: Synthesis, structure, DNA binding, alkaline phosphatase inhibition, biological screening, and insulin mimetic properties. Russ. J. Gen. Chem. 2015, 85, 2183-2197.

17. Gaber, M.; El-Ghamry, H.; Fathalla, S. Ni(II), Pd(II) and Pt(II) complexes of $(1 H-1,2,4-$ triazole-3-ylimino)methyl]naphthalene-2-ol. Structural, spectroscopic, biological, cytotoxicity, antioxidant and DNA binding. Spectrochim. ActaA Mol. Biomol. Spectrosc. 2015, 139, 396-404.

18. Prakash, A.; Adhikari, D., Application of Schiff bases and their metal complexes-A review. Intern. J. Chem. Tech. Res. 2011, 3, 1891-1896. 
19. Sumrra, S.H.; Sahrish, I.; Raza, M.A.; Ahmad, Z.; Zafar, M.N.; Chohan, Z.H.; Khalid, M.; Ahmed, S. Efficient synthesis, characterization, and in vitro bactericidal studies of unsymmetrically substituted triazole-derived Schiff base ligand and its transition metal complexes. Monatsh. Chem. 2020, 151, 549-557.

20. Rahman, A.U., Choudhary, M.I., Thomsen, W.J., Bioassay Techniques for Drugs Development, Harwood Academic Publishers: Amsterdam; 2001; pp. 14-21.

21. Gaber, M.; El-Ghamry, H.A.; Fathalla, S.K.; Mansour, M.A. Synthesis, spectroscopic, thermal and molecular modeling studies of $\mathrm{Zn}^{2+}, \mathrm{Cd}^{2+}$ and $\mathrm{UO}_{2}{ }^{2+}$ complexes of Schiff bases containing triazole moiety. Antimicrobial, anticancer, antioxidant and DNA binding studies. Mater. Sci. Eng. C 2018, 83, 78-89.

22. Matkowski, A.; Piotrowska, M. Antioxidant and free radical scavenging activities of some medicinal plants from the Lamiaceae. Fitoterapia 2006, 77, 346-353.

23. Zubair, M.; Anwar, F.; Shahid, S. A., Effect of extraction solvents on phenolics and antioxidant activity of selected varieties of Pakistani rice (Oryza sativa). Int. J. Agric. Biol. 2012, 14, 935-940.

24. Rahbar, S.; Figarola, J.L. Novel inhibitors of advanced glycation end products. Arch. Biochem. Biophys. 2003, 419, 63-79.

25. Nejati, K.; Bakhtiari, A.; Bikas, R.; Rahimpour, J. Molecular and electronic structure, spectroscopic and electrochemical properties of copper(II) complexes: Experimental and DFT studies. J. Mol. Struct. 2019, 1192, 217-229.

26. Asad, M.; Arshad, M.N.; Khan, S.A.; Oves, M.; Khalid, M.; Asiri, A.M.; Braga, A.A.C. Cyclization of chalcones into N-propionylpyrazolines for their single crystal X-ray, computational and antibacterial studies. J. Mol. Struct. 2020, 1201, 127186.

27. Chohan, Z.H. Hanif, M. Synthesis and characterization of biologically active new Schiff bases containing 3-functionalized 1,2,4-triazoles and their zinc(II) complexes: Crystal structure of 4-bromo-2-[(E)-(1H-1,2,4-triazol-3-ylimino)-methyl] phenol. Appl. Organomet. Chem. 2011, 25, 753-760.

28. Nassar, M.Y.; Aly, H.M.; Abdelrahman, E.A.; Moustafa, M.E. Synthesis, characterization, and biological activity of some novel Schiff bases and their $\mathrm{Co}(\mathrm{II})$ and Ni(II) complexes: A new route for $\mathrm{Co}_{3} \mathrm{O}_{4}$ and $\mathrm{NiO}$ nanoparticles for photocatalytic degradation of methylene blue dye. J. Mol. Struc. 2017, 1143, 462-471.

29. Amer, S.; El-Wakiel, N.; El-Ghamry, H. Synthesis, spectral, antitumor and antimicrobial studies on $\mathrm{Cu}(\mathrm{II})$ complexes of purine and triazole Schiff base derivatives. J. Mol. Struct. 2013, 1049, 326-335.

30. Tyagi, P.; Chandra, S.; Saraswat, B.; Yadav, D. Design, spectral characterization, thermal, DFT studies and anticancer cell line activities of $\mathrm{Co}(\mathrm{II}), \mathrm{Ni}(\mathrm{II})$ and $\mathrm{Cu}(\mathrm{II})$ complexes of Schiff bases derived from 4-amino-5-(pyridin-4-yl)-4H-1,2,4-triazole-3-thiol. Spectrochim. Acta A Mol. Biomol. Spectrosc. 2015, 145, 155-164.

31. Calu, L.; Badea, M.; Chifiriuc, M.C.; Bleotu, C.; David, G.I.; Ioniţă, G.; Măruţescu, L.; Lazăr, V.; Stanică, N.; Soponaru, I. Synthesis, spectral, thermal, magnetic and biological characterization of $\mathrm{Co}(\mathrm{II}), \mathrm{Ni}(\mathrm{II}), \mathrm{Cu}(\mathrm{II})$ and $\mathrm{Zn}(\mathrm{II})$ complexes with a Schiff base bearing a 1,2,4-triazole pharmacophore. J. Therm. Anal. Calorim. 2015, 120, 375-386.

32. Sumrra, S.H.; Mushtaq, F.; Khalid, M.; Raza, M.A.; Nazar, M.F;, Ali, B.; Braga, A.A.C. Synthesis, spectral characterization and computed optical analysis of potent triazole based compounds. Spectrochim. ActaA Mol. Biomol. Spectrosc. 2018, 190, 197-207.

33. Utthra, P.P.; Pravin, N.; Raman, N. Scrutinizing the DNA damaging and antimicrobial abilities of triazole appended metal complexes. J. Photochem. Photobiol. B Biol. 2016, 158, 136-144.

34. Hanif, M.; Chohan, Z.H. Design, spectral characterization and biological studies of transition metal(II) complexes with triazole Schiff bases. Spectrochim. Acta A Mol. Biomol. Spectrosc. 2013, 104, 468-476. 
Synthesis, structural, spectral and biological evaluation of metals endowed 1,2,4-triazole 351

35. Raza, A.R.; Nisar, B.; Khalid, M.; Gondal, H.Y.; Khan, M.U.; de Alcântara Morais, S.F.; Tahir, M.N.; Braga, A.A.C. A facile microwave assisted synthesis and structure elucidation of (3R)-3-alkyl-4,1-benzoxazepine-2,5-diones by crystallographic, spectroscopic and DFT studies. Spectrochim. Acta A Mol. Biomol. Spectrosc. 2020, 230, 117995.

36. Sumrra, S.H.; Hassan, A.U.; Imran, M.; Khalid, M.; Mughal, E.U.; Zafar, M.N.; Tahir, M.N.; Raza, M.A.; Braga, A.A.C. Synthesis, characterization, and biological screening of metal complexes of novel sulfonamide derivatives: Experimental and theoretical analysis of sulfonamide crystal. Appl. Organomet. Chem. 2020, 34, 1-19.

37. Mermer, A.; Bayrak, H.; Alyar, S.; Alagumuthu, M. Synthesis, DFT calculations, biological investigation, molecular docking studies of $\beta$-lactam derivatives. J. Mol. Struct. 2020, 1208, 127891.

38. Ali, A.; Din, Z. U.; Khalid, M.; Tahir, M.N.; Rodrigues-Filho, E.; Ali, B.; Asim, S.; Muhammad, S. Crystal and quantum chemical exploration of the potent monocarbonylcurcuminoids to unveil their structural and intriguing electronic properties. Chemistry Select 2020, 5, 3735-3745.

39. Sumrra, S.H.; Suleman, A.; Chohan, Z.H.; Zafar, M.N.; Raza, M.A; Iqbal, T. Triazole metal based complexes as antibacterial/antifungal agents. Russ. J. Gen. Chem. 2017, 87, 12811287.

40. Sumrra, S.H.; Kausar, S.; Raza, M.A.; Zubair, M.; Zafar, M.N.; Nadeem, M.A.; Mughal, E.U.; Chohan, Z.H.; Mushtaq, F.; Rashid, U. Metal based triazole compounds: Their synthesis, computational, antioxidant, enzyme inhibition and antimicrobial properties. $J$. Mol. Struct. 2018, 1168, 202-211. 